\title{
EFISIENSI PENGGUNAAN RANSUM SAPI BALI JANTAN YANG DISUBTITUSI DENGAN AMPAS TAHU DAN DEDAK PADI FERMENTASI
}

\author{
Khoirul Mualimin, Natsir Sandiah, La Ode Baa \\ 1) Alumnus Fakultas Peternakan UHO \\ ${ }^{2)}$ Dosen Fakultas Peternakan UHO
}

\begin{abstract}
ABSTRAK
Penelitian ini bertujuan untuk mengetahui efisiensi penggunaan ransum sapi Bali jantan yang disuntitusi dengan ampas tahu dan dedak padi fermentasi. Penelitian ini dilaksanakan selama sembilan minggu di Laboratorium Ilmu Nutrisi dan Makanan Ternak Jurusan Peternakan Fakultas Peternakan Universitas Haluoleo Kendari dan di desa Alebo kecamatan Konda Kabupaten Konawe Selatan. Perlakuan yang dicobakan adalah $\mathrm{R} 0=$ konsentrat berbasis pakan tanpa fermentasi (kontrol), $\mathrm{R} 1=$ konsentrat berbasis dedak padi fermentasi $50 \%, \mathrm{R} 2=$ konsentrat berbasis dedak padi fermentasi $55 \%$ dan R3= konsentrat berbasis dedak padi fermentasi $60 \%$. Rancangan percobaan yang digunakan adalah Rancangan Acak Kelompok (RAK) dengan 4 perlakuan dan 3 ulangan (blok/kelompok). Hasil analisis ragam menunjukkan bahwa dengan subtitusi ampas tahu dan dedak padi fermentasi sampai $60 \%$ dalam ransum tidak berpengaruh nyata $(p>0,05)$ terhadap pertambahan bobot badan sapi Bali jantan, akan tetapi secara kuantitaif ransum R3 memberikan respon yang lebih baik dibanding R0, R1 dan R2 (0,542 kg/ekor/hari dibanding 0,402 kg/ekor/hari, 0,411 kg/ekor/hari dan 0,435 kg/ekor/hari). Konsumsi bahan kering ransum tidak berbeda nyata $(p>0,05)$, dimana rataan konsumsi bahan kering dari yang tertinggi sampai terendah adalah R1 (5,143 kg/ekor/hari), R0 (5,063 kg/ekor/hari), R3 (4,907 kg/ekor/hari) dan R2 (4,864 kg/ekor/hari). Sedangkan efisiensi penggunaan ransum R3 $(10,888 \%)$ lebih tinggi dibandingkan R2 (9,027\%), R1 (8,080\%) dan R0 (8,075\%). Kesimpulan bahwa subtitusi dedak padi fermentasi sampai $60 \%$ dalam ransum dapat memberikan efisiensi penggunaan ransum sapi Bali jantan yang lebih baik.
\end{abstract}

Kata Kunci: Sapi Bali, PBB, Konsumsi bahan kering, Efisiensi ransum, Dedak padi fermentasi

\begin{abstract}
This research aims to know the efficiency of ration use of a male Bali cattle in substitution with tofu dregs and rice bran fermentation. This research was conducted during nine weeks in Nutrition and Animal Feed Laboratory of Animal Science Department of Animal Science Faculty, Halu Oleo University, Kendari, and in Alebo Village of Konda Subdistrict of South Konawe Regency. The treatments were $\mathrm{R} 0=$ concentrate without fermentation-based feed (control), $\mathrm{R} 1=$ rice bran fermnetation-based concentrate $50 \%, \mathrm{R} 2=$ rice bran fermnetation-based concentrate $55 \%, \mathrm{R} 3=$ rice bran fermnetation-based concentrate $60 \%$. The experimental design used in this study was randomly group design with 4 traetments and 3 block/group. The result of variance analysis showed that dry matter concumption was not differ markedly $(p>0,05)$, which justifies the dry matter concumption is average from the highest to the lowest is R1 (5,143 kg/cattle/day), R0 (5,063 kg/cattle/day), R3 (4,907 $\mathrm{kg} /$ cattle/day) and $\mathrm{R} 2(4,905 \mathrm{~kg} / \mathrm{cattle} / \mathrm{day})$. The substitution tofu dregs know and rice bran fermentation to $60 \%$ in ration not effect real $(p>0,05)$ addition average daily againt of a male Bali cattle, but in quantitative R3 rations give a good response better than R0, R1 and R2 $(0,542$ $\mathrm{kg} /$ cattle/day than $0,402 \mathrm{~kg} /$ cattle/day, $0,411 \mathrm{~kg} / \mathrm{cattle} / \mathrm{day}$ and $0,435 \mathrm{~kg} /$ cattle/day). While the efficiency of used R3 rations (10,888\%) higher than R2 $(9,027 \%)$, R1 $(8,080 \%)$ and R0 $(8,075 \%)$. Conclusion that in substitution tofu dregs and rice bran fermentation to $60 \%$ in rations can give a good the efficiency of ration used of a male Bali cattle.
\end{abstract}

Key Words: Bali cattle, dry matter consumption, feed efficiency, rice bran fermentation 


\section{PENDAHULUAN}

Indonesia memiliki beberapa jenis sapi lokal yang menjadi plasma nutfah dan secara turun-temurun dipelihara dan diusahakan oleh para peternak. Keberadaan sapi lokal tersebut tersebar di hampir semua wilayah Indonesia. Wilayah yang memiliki populasi sapi lokal yang cukup banyak, potensi pakan memadai dan kondisi sosial ekonomi masyarakat yang mendukung, merupakan suatu wilayah yang memiliki potensi sebagai sumber penyediaan bibit sapi lokal. Salah satu contoh sapi lokal Indonesia adalah sapi Bali. TANARI (2001) mengemukakan bahwa sampai saat ini penyebaran populasi sapi Bali telah meluas hampir mencakup seluruh wilayah Indonesia termasuk di Pulau Jawa kecuali Provinsi DKI Jakarta. Konsentrasi sapi Bali terbesar adalah di Sulawesi Selatan, Pulau Timor, Bali, Lombok, NTB, NTT, Maluku dan Irian.

Sapi Bali merupakan sapi asli Indonesia dengan ciri - ciri yang khas antara lain: warna bulu merah bata, tetapi pada jantan dewasa berubah menjadi hitam (HARDJOSUBROTO, 1994). Selain itu sapi Bali memiliki efisiensi reproduksi yang tinggi, daging dan karkasnya berkualitas baik dan persentase karkasnya tinggi, daya adaptasinya terhadap lingkungan tropis yang ekstrim sangat baik, dan kemampuannnya dalam menggunakan sumber pakan yang terbatas dan kualitas rendah. SIREGAR (2008) menambahkan peresentase karkas sapi Bali berdasarkan penelitian terdahulu berkisar 51,5 - 59\% dan pertambahan bobot badannya dapat mencapai $0,7 \mathrm{~kg} /$ hari apabila mendapatkan pakan yang baik. Provinsi Sulawesi Tenggara sebagai salah satu daerah pengembangan sapi Bali.

Hal ini didukung dengan luas wilayah daratan yang cukup potensial untuk pengembangan ternak sapi Bali.
Kecenderungan tak dapat dihindari, bahwa dengan bertambahnya jumlah penduduk dan makin meluasnya lahan pertanian, perkebunan dan pemukiman penduduk akan semakin mempersempit luas lahan, termasuk proyeksi lahan untuk padang penggembalaan, sehingga ketergantungan pakan ternak asal hijauan saja akan semakin sulit didapatkan oleh peternak, terutama di daerah persawahan. Sementara itu, penggunaan limbah pertanian dan industri sebagai makanan ternak sapi masih belum dimanfaatkan dengan baik. Karena secara kuantitas melimpah, namun secara teknis belum banyak diketahui, terutama dalam meningkatkan kualitas limbah sebagai makanan ternak masih terbatas.

Penggilingan satu ton gabah akan menghasilkan dedak sebanyak $60-80 \mathrm{~kg}$, tergantung pada kualitas gabah dan varietas padi, derajat penggilingan dan penyosohannya (ARIFAN, 2011 dan IRIANINGRUM, 2009)). Potensi dedak padi di Sulawesi Tenggara, berdasarkan produksi gabah 454.644 ton/tahun akan menghasilkan dedak sebanyak 28.415 ton/tahun (ANONIMOUS, 2011).Dedak padi merupakan hasil sampingan penggilingan padi yang biasanya terdiri atas lapisan dedak, sedikit pecahan sekam dan menir. Dedak padi merupakan sumber energi bagi ternak, disamping sebagai sumber vitamin B yang cukup baik. Dedak padi merupakan ingredient yang bersifat hipoalergenik (bebas alergi) dan merupakan sietary fiber (sumber serat) yang baik (HADIPERMATA, 2006). Fluktuasi kadar nutrisi dedak padi disebabkan oleh perbedaan cara penggilingan dan kontaminasi dengan bahan asing, sehingga perlu dilakukan aplikasi teknologi untuk meningkatkan nilai nutrisi dedak padi. Selain itu, dedak padi rata-rata mengandung $80 \%$ fitatfosfor dari $P$ total. Senyawa fitat digolongkan sebagai zat antinutrisi karena kemampuannya mengikat mineral $(\mathrm{P}, \mathrm{Ca}$, $\mathrm{Zn}, \mathrm{Mg}, \mathrm{Fe}$ ) dan protein (RAO, 1999 dalam PUJANINGSIH, 2004). Sebagian fosfor yang 
tidak dapat dimanfaatkan dibuang bersama feses yang akibatnya lebih jauh dapat mencemari lingkungan. Oleh karena itu, kualitas nutrisi dedak padi perlu ditingkatkan dengan teknologi pengolahan pakan yang aplikatif dengan harapan mikroba penghasil enzim fitase dapat mendegradasi fitat-fosfor sehingga fosfor dan mineral lain serta protein dapat dimanfaatkan dengan baik. Penambahan ragi tape dalam ransum dapat menambah ketersediaan mineral.

Fermentasi dengan penambahan ragi tape dapat menambah ketersediaan mineral dan memperbaiki gizi bahan pakan berkualitas rendah dengan melibatkan mikroorganisme yang bekerja secara bilogis. Fermentasi dapat meningkatkan kualitas nutrisi bahan pakan, karena pada proses fermentasi terjadi perubahan kimiawi senyawa-senyawa organik (karbohidrat, lemak, protein, serat kasar dan bahan organik lain) baik dalam keadaan aerob maupun anaerob, melalui kerja enzim yang dihasilkan mikroba. HIDAYAT (2010) dan NURHAITA (2012) menambahkan fermentasi adalah proses pengolahan bahan dengan bantuan mikroba yang mampu memecah komponen kompleks menjadi bentuk yang lebih sederhana misalkan selulosa dan hemiselulosa menjadi glukosa, pati dan gula menjadi alcohol dan karbon dioksida. Saccharomyces cerevisiae merupakan mikroba yang terdapat di dalam ragi tape yang dapat memecah senyawa-senyawa karbohidrat. Oleh karena itu, perlu dilakukan penelitian tentang efisiensi penggunaan ransum sapi Bali jantan yang disubtitusi dengan dedak padi fermentasi.
Penelitian ini bertujuan untuk mengetahui efisiensi penggunaan ransum (konsumsi ransum, pertambahan bobot badan dan $\%$ efisiensi penggunaan ransum) sapi Bali jantan yang disubtitusi dengan ampas tahu dan dedak padi fermentasi.

\section{MATERI DAN METODE}

Penelitian ini dilaksanakan selama sembilan minggu, bertempat di Laboratorium Ilmu Nutrisi dan Makanan Ternak Jurusan Peternakan Fakultas Peternakan Universitas Haluoleo Kendari dan di Desa Alebo Kecamatan Konda Kabupaten Konawe Selatan.

Pembuatan pakan fermentasi dilakukan dengan cara bahan pakan dikeringkan kemudian dimasukkan dalam wadah dan ditambah air (1 liter air : $3 \mathrm{~kg}$ bahan pakan), selanjutnya ditambah ragi tape $1 \%$ dari berat bahan. Wadah selanjutnya ditutup rapat dan diinkubasi selama 2 hari (48 jam), setelah diperoleh pakan fermentasi kemudian dikeringkan dan diformulasi menjadi konsentrat.

Rancangan yang digunakan adalah Rancangan Acak Kelompok (RAK) yang terdiri atas 4 perlakuan dan 3 kelompok/blok. Bobot badan sapi yang digunakan yaitu kelompok $1=90-110 \mathrm{~kg}$, kelompok $2=111-$ $130 \mathrm{~kg}$ dan kelompok $3=13-150 \mathrm{~kg}$. Perlakuan pakan yang diberikan adalah rumput alam dan konsentrat, dimana $\mathrm{R} 0=$ rumput alam + konsentrat berbasis dedak padi tanpa fermentasi $60 \%, \mathrm{R} 1=$ rumput alam + konsentrat berbasis dedak padi fermentasi $50 \%, \mathrm{R} 2=$ rumput alam + konsentrat berbasis dedak apdi fermentasi 55\% dan R3= rumput alam + konsentrat berbasis dedak padi fermnetasi $60 \%$. Komposisi bahan baku konsentrat dapat dilihat pada tabel berikut:

Tabel 1. Perlakuan Pakan Penelitian

\begin{tabular}{lcccc}
\hline \multirow{2}{*}{ Bahan Baku } & \multicolumn{4}{c}{ Perlakuan } \\
\cline { 2 - 5 } & $\mathbf{R 0}(\boldsymbol{\%})$ & $\mathbf{R 1}(\boldsymbol{\%})$ & $\mathbf{R 2}(\boldsymbol{\%})$ & $\mathbf{R 3}(\boldsymbol{\%})$ \\
\hline Dedak Padi Fermentasi & - & 50 & 55 & 60 \\
Dedak padi tanpa fermentasi & 60 & - & - & - \\
Ampas Sagu Fermentasi & - & 27,5 & 22,5 & 17,5 \\
Ampas sagu tanpa fermentasi & 17.5 & - & - & - \\
Ampas Tahu & 22 & 22 & 22 & 22 \\
Garam (NaCl) & 0,5 & 0,5 & 0,5 & 0,5 \\
\hline \multicolumn{1}{c}{ Jumlah (\%) } & $\mathbf{1 0 0}$ & $\mathbf{1 0 0}$ & $\mathbf{1 0 0}$ & $\mathbf{1 0 0}$ \\
\hline
\end{tabular}


Variable yang diamati adalah:

1. Konsumsi ransum $=\sum$ ransum yang diberikan $-\sum$ ransum sisa

2. PBB Harian $=$

Bobot Badan Akhir - Bobot Badan Awal lama Pemeliharaan

3. Efisiensi Penggunaan Ransum = $\frac{\sum \text { PBB yang dihasilkan }}{\sum \text { ransum yang dikonsumsi }} \times 100 \%$

HASIL DAN PEMBAHASAN
Hasil penelitian pendahuluan selama satu minggu menunjukkan bahwa ransum pada perlakuan R0 memiliki tingkat palatabilitas yang lebih tinggi dibandingkan R3, R2 dan R1. Hal ini disebabkan karena pada perlakuan R0 merupakan konsentrat tanpa fermentasi, sedangkan konsentrat R3, R2 dan R1 merupakan konsentrat te ${ }^{\circ} \cdot$ akan tetapi R3 mempunyai pala1 s lebih baik dibandingkan ransum $\cong<$ uaı $\cong$ karena persentase dedak padi terfermentasi lebih besar yaitu $60 \%$ dan ampas sagu terfermentasi $17,5 \%$. Rataan konsumsi bahan kering konsentrat selama penelitian dapat dilihat pada Tabel 2.

\section{Konsumsi Bahan Kering Ransum}

Tabel 2. Rataan konsumsi bahan kering ransum selama penelitian (kg/ekor/hari)

\begin{tabular}{cccccc}
\hline \multirow{2}{*}{ Kelompok } & \multicolumn{4}{c}{ Perlakuan } & Total \\
\cline { 2 - 5 } & $\mathrm{R} 0$ & $\mathrm{R} 1$ & $\mathrm{R} 2$ & $\mathrm{R} 3$ & Kelompok \\
\hline 1 & 3.789 & 3.553 & 3.615 & 3.624 & 14.581 \\
2 & 5.259 & 5.352 & 4.970 & 5.308 & 20.889 \\
3 & 6.141 & 6.525 & 6.007 & 5.790 & 24.463 \\
\hline Total Perlakuan & 15.189 & 15.430 & 14.592 & 14.722 & $\mathbf{5 9 . 9 3 3}$ \\
\hline Rata-Rata & 5.063 & 5.143 & 4.864 & 4.907 & $\mathbf{4 . 9 9 4}$ \\
& \pm 1.19 & \pm 1.50 & \pm 1.20 & \pm 1.14 & \\
\hline
\end{tabular}

Berdasarkan hasil analisis sidik ragam menunjukkan bahwa subtitusi dedak padi sampai $60 \%$ yang diberikan pada sapi Bali jantan tidak menunjukkan pengaruh yang nyata $(p<0.05)$ terhadap konsumsi bahan kering ransum. Kecenderungan konsumsi bahan kering sapi Bali pada perlakuan R0 lebih tinggi dibandingkan R1, R2 dan R3 kemungkinan disebabkan oleh tingginya palatabillitas dan kadar bahan kering konsentrat R0 sehingga bahan kering yang terkonsumsi berbanding lurus. Sedangkan ransum R1, R2 dan R3 merupakan ransum fermentasi sehingga palatabilitasnya lebih rendah. Hal lain yang menyebabkan rendahnya konsumsi bahan kering ransum fermentasi adalah sifat eliminatif yang dimiliki sapi Bali dalam memilih pakan. Akan tetapi secara rataan menunjukkan bahwa bahan kering pada ransum R1 dikonsumsi lebih banyak $(5,143 \mathrm{~kg} / \mathrm{ekor} / \mathrm{hari})$ dibanding konsumsi bahan kering ransum R0 (5,063 $\mathrm{kg}$ /ekor/hari) dan R3 (4,907 kg/ekor/hari), sedangkan konsumsi bahan kering yang paling rendah adalah ransum R2 (4,864 kg/ekor/hari).
Hal ini karena persentase ampas sagu fermentasi pada ransum R1 lebih tinggi sehingga kemungkinan besar kadar serat kasarnya juga lebih tinggi dengan demikian sapi percobaan tidak dapat memanfaatkan pakan dengan baik untuk dikonversikan menjadi pertambahan bobot badannya. Perbedaan konsumsi bahan kering ransum selama penelitian diduga akibat pengaruh pertambahan bobot badan, jumlah pakan yang dikonsumsi, kecernaan dan kadar protein serta energi yang terdapat dalam ransum (SUSANTO, 2004). Makin tinggi bobot hidup ternak kapasitas lambung (rumen, retikulum, omasum dan abomasum) dan saluran pencernaan semakin besar sehingga ternak makin banyak mengkonsumsi pakan. (PARAKKASI, 1999; ZAID, 2009). Selanjutnya dijelaskan bahwa bobot hidup akan mempengaruhi kebutuhan nutrisi untuk hidup pokok, dan kebutuhan tersebut dipengaruhi oleh konsumsi pakan.

\section{Pertambahan Bobot Badan Sapi}

Hasil penimbangan berat badan sapi percobaan selama penelitian berdasarkan 
perlakuan yang diberikan dapat dilihat pada Tabel 3. Rataan pertambahan bobot badan tertinggi pada penelitian ini ditunjukkan oleh sapi percobaan yang mendapat perlakuan R3 (konsentrat berbasis dedak padi terfermentasi $60 \%$ ) dibandingkan dengan ketiga perlakuan lainnya. Hal ini kemungkinan disebabkan pakan berbasis fermentasi memiliki tingkat kecernaan yang tinggi, sehingga ransum yang diberikan dapat dimanfaatkan dengan baik untuk pertumbuhan. Rataan pertambahan bobot badan sapi selama penelitian dapat dilihat pada Tabel 3.

Tabel 3. Rataan pertambahan bobot badan sapi Bali jantan (kg/ekor/hari)

\begin{tabular}{cccccc}
\hline \multirow{2}{*}{ Kelompok } & \multicolumn{4}{c}{ Perlakuan } & $\begin{array}{c}\text { Total } \\
\text { Kelompok }\end{array}$ \\
\cline { 2 - 4 } & $\mathrm{R} 0$ & $\mathrm{R} 1$ & $\mathrm{R} 2$ & $\mathrm{R} 3$ & 1.384 \\
2 & 0.384 & 0.313 & 0.339 & 0.348 & 1.866 \\
3 & 0.384 & 0.402 & 0.473 & 0.607 & 2.117 \\
\hline Total Perlakuan & 0.438 & 0.518 & 0.491 & 0.670 & $\mathbf{5 . 3 6 7}$ \\
\hline Rata-Rata & 1.206 & 1.233 & 1.303 & 1.625 & $\mathbf{0 . 4 4 7}$ \\
& 0.402 & 0.411 & 0.434 & 0.542 & \\
\hline
\end{tabular}

Lama waktu penggemukan dan kondisi fisiologis ternak sangat mempengaruhi pertumbuhan yang dialami ternak tersebut, dimana ternak yang kurus akan mengalami pertumbuhan yang lebih baik ketika mendapatkan manajemen pakan yang baik. Selain itu, kualitas dan kuantitas ransum juga mempengaruhi tingkat konsumsi bahan kering sehingga berdampak langsung terhadap pertambahan bobot badan yang dihasilkan. Beberapa faktor yang membatasi kemampuan sapi dalam mengkonsumsi ransum adalah faktor dari ternak itu sendiri, keadaan ransum dan faktor luar lainnya seperti suhu dan kelembaban. GIVENS (2000) menyatakan bahwa kehadiran residu bahan pakan yang tidak dapat dicerna dalam saluran pencernaan akan membatasi tingkat konsumsi bahan makanan, sehingga dapat menurunkan kemampuan bertumbuh ternak.

Hasil analisis sidik ragam menunjukkan bahwa subtitusi dedak padi fermentasi sampai $60 \%$ tidak berpengaruh nyata $(p>0,05)$ terhadap pertambahan bobot badan sapi percobaan selama penelitian. Akan tetapi apabila dilihat dari rata-rata pada setiap perlakuan, dapat diartikan bahwa sapi percobaan yang mendapat perlakuan R3 mempunyai tingkat efisiensi yang baik dalam menggunakan ransum. Dimana pertambahan bobot badan sapi yang mengkonsumsi jenis ransum R3 mengahsilkan pertambahan bobot badan lebih tinggi $(0,542 \mathrm{~kg} / \mathrm{ekor} / \mathrm{hari})$ dibandingkan dengan pertambahan bobot badan yang dihasilkan sapi dengan ransum R2 $(0,434 \mathrm{~kg} / \mathrm{ekor} / \mathrm{hari}), \mathrm{R} 1$ (0,411 kg/ekor/hari) dan R0 (0,402 kg/ekor/hari). Sedangkan hasil penelitian Zain (2009) pada sapi Bali jantan muda yang diberi ransum komplit menghasilkan pertambahann bobot badan berkisar $0,480-0,770 \mathrm{~kg} / \mathrm{ekor} / \mathrm{hari}$.

Tidak adanya pengaruh perlakuan terhadap pertambahan bobot badan yang dihasilkan, disebabkan bahwa ransum yang diberikan tidak dapat dimanfaatkan dengan baik oleh sapi percobaan karena ampas sagu dan rumput alam merupakan pakan yang memiliki serat kasar tinggi. ABIDIN (2002) mengemukakan bahwa program penggemukan hanya mengandalkan bahan pakan berupa hijauan, kurang memberikan hasil yang optimum dan membutuhkan waktu yang cukup lama. Salah satu cara mempercepat proses penggemukan memerlukan kombinasi antara pakan hijauan dan konsentrat.

\section{Efisiensi Penggunaan Ransum}

Efisiensi penggunaan ransum sapi Bali jantan yang disubtitusi dengan dedak padi fermentasi dan ampas tahu selama penelitian disajikan pada Tabel 4. 
Tabel 4. Rataan efisiensi penggunaan ransum selama penelitian (\%)

\begin{tabular}{cccccc}
\hline \multirow{2}{*}{ Kelompok } & \multicolumn{4}{c}{ Perlakuan } & Total \\
\cline { 2 - 5 } & $\mathrm{R} 0$ & $\mathrm{R} 1$ & $\mathrm{R} 2$ & $\mathrm{R} 3$ & Kelompok \\
\hline 1 & 10.139 & 8.795 & 9.385 & 9.661 & 37.980 \\
2 & 6.962 & 7.510 & 9.523 & 11.438 & 35.433 \\
3 & 7.125 & 7.935 & 8.174 & 11.566 & 34.800 \\
\hline Total & 24.226 & 24.240 & 27.082 & 32.665 & $\mathbf{1 0 8 . 2 1 3}$ \\
Perlakuan & 8.075 & 8.080 & 9.027 & 10.888 & $\mathbf{9 . 0 1 8}$ \\
Rata-Rata & \pm 1.79 & \pm 0.65 & \pm 0.74 & \pm 1.06 & \\
\hline
\end{tabular}

Rataan efisiensi penggunaan ransum sapi Bali jantan dari yang tertinggi sampai terendah adalah ransum R3 (ransum berbasis dedak padi fermentasi $60 \%$ + rumput alam) sebesar 10,888\%, R2 (ransum berbasis dedak padi fermentasi $55 \%$ + rumput alam) sebesar $9,027 \%$, R1 (ransum berbasis dedak padi fermentasi $50 \%+$ rumput alam) sebesar $8,080 \%$ dan R0 (ransum berbasis dedak padi $60 \%$ + rumput alam) sebesar $8,075 \%$. Hasil ini berbeda dengan hasil penelitian Zain (2009) bahwa sapi Bali jantan muda yang diberi ransum komplit menghasilkan nilai efisiensi penggunaan ransum antara 13,4 $21,3 \%$.

Berdasarkan hasil analisis sidik ragam menunjukkan bahwa subtitusi dedak padi fermentasi sampai $60 \%$ dalam ransum tidak berpengaruh nyata $(p>0,05)$ terhadap efisiensi penggunaan ransum sapi Bali jantan selama penelitian. Meskipun demikian secara kuantitaif ransum R3 lebih baik dibandingkan R2, R1 dan R0, sedangkan R1 dan R0 tidak menunjukkan perbedaan yang signifikan. Efisiensi penggunaan ransum R2, R1 dan R0 lebih rendah dibanding ransum R3, ransum R2 lebih tinggi dibanding R0 dan R1 secara kuantitatif merupakan hasil akumulasi dari kandungan nutrisi ransum yang tersedia.

PARAKKASI (1999) menyatakan bahwa untuk menilai pemberian ransum atau kualitas ransum yang lebih baik adalah dengan melihat pertumbuhan atau pertambahan bobot badan karena hal ini mencerminkan bagaimana protein dan keseimbangan asam-asam amino yang ada dalam ransum memberikan dampak positif bagi ternak. Dengan demikian sapi pada perlakuan R3 lebih efisien dalam mengguakan efisiensi ransum, karena dapat menghasilkan pertambahan bobot badan yang lebih baik dibanding ketiga perlakuan lainnya.
Lebih lanjut dapat dijelaskan bahwa dengan penggunaan dedak padi fermentasi $(60 \%)$ dalam formulasi ransum masih memberikan suplai nutrisi yang seimbang, dimana ransum yang dikonsumsi selain memberikan kontribusi protein juga memberikan kontribusi energi serta terpenuhinya kebutuhan mineral, sehingga ransum yang dikonsumsi dapat dikonversikan menjadi pertambahan bobot badan yang baik. HAFID (2010) menyatakan bahwa kinerja pertumbuhan sapi dijabarkan sebagai laju pertambahan bobot badan harian, jumlah konsumsi pakan dalam bentuk bahan kering dan konversi ransum sebagai acuan efisiensi ternak sapi dalam menggunakan ransum.

\section{KESIMPULAN}

1. Subtitusi dedak padi fermentasi sampai $60 \%$ dalam ransum tidak menunjukkan perbedaan yang nyata pada taraf $5 \%(p \quad 0,05)$ terhadap pertambahan bobot badan, konsumsi bahan kering ransum, dan efisiensi penggunaan ransum.

2. Konsumsi bahan kering ransum, pertambahan bobot badan, dan efisiensi penggunaan ransum yang disubtitusi dengan ampas tahu dan dedak padi fermentasi $60 \%$ memberikan hasil yang lebih baik dibandingkan 50\%, 55\% dan pakan tanpa fermentasi. 


\section{DAFTAR PUSTAKA}

Abidin, Z., 2002. Penggemukan Sapi Potong. Agro Media Pustaka. Jakarta.

Arifan, F., M.E. Yulianto, D.K. Wikanta dan N. Damayanti., 2011. Pengembangan bioreaktor enzimatik untuk produksi asam lemak dari hasil samping penggilingan padi secara in situ. Prosiding Seminar Nasional Teknik Kimia "Kejuangan" Yogyakarta, 22 Februari 2011. ISSN 1693 - 4393

Anonimous., 2011. Produksi Padi Sultra. Kendari : Badan Pusat Statistik (BPS) Sulawesi Tenggara.

Givens., D.I., E. Owen, R.F.E. Axford and H.M. Omed. 2000. Forage Evaluationin Ruminant Nutrition. CABI Publishing. New York. USA.

Hadipermata, M. 2006. Mengolah dedak menjadi minyak (rice bran oil). Balai Besar Penelitian dan Pengembangan Pascapanen Pertanian. Bogor.

Hafid, H. dan N. Rugayah. 2010. Pengukuran pertumbuhan sapi bali dengan ransum berbahan baku lokal. Jurusan Peternakan Fakultas Pertanian Universitas Haluoleo dalam Seminar Nasional Teknologi Peternakan dan Veteriner 2010. Kendari.

Hardjosubroto, W. 1994. Pola Pembiakan dan Output Sapi Potong Di Daerah Istimewa Yogyakarta. Buletin Peternakan, Volume 16.

Hidayat, N. dan Suhartini, S. 2010. Mikrobiologi Industri. Universitas Brawijaya. Malang.

Irianingrum, R. 2009. Kandungan asam fitat dan kualitas dedak padi yang disimpan dalam keadaan anaerob. Fakultas Peternakan. Institut Pertanian Bogor.

Nurhaita., 2012. Fermentasi bagase tebu dengan neurospora sitophila dan pengaruhnya terhadap nilai gizi dan kecernaan secara in vitro. Fakultas Pertanian UniversitasMuhammadiyah Bengkulu. Bengkulu.

Parakkasi, A.1999. Ilmu Nutrisi dan Makanan Ternak Ruminan. Penerbit Universitas Indonesia Press. Jakarta.

Pujaningsih, R.I. 2004. Aktivitas enzim dalam upaya peningkatan ketersediaan fosfor pada fermentasi dedak padi dengan cairan rumen. Fakultas Peternakan Universitas Diponegoro.

Semarang.

Rao, S.V.R, V.R. Reddy, and R.V. Ravindran. 1999. Enhancement of phytate phosphorus availability in the diets of commercial broilers and layers. J. Anim.Feed Sci. Technol. 79: $211-222$.

Siregar, S.B. 2008. Penggemukan Sapi. Penebar Swadaya. Jakarta.

Susanto, S.A., E. Rianto dan J.A. Prawoto. 2004. Pengaruh penggantian konsentrat dengan ampas bir terhadap penampilan produksi sapi peranakan ongole yang mendapat pakan basal rumput raja. Pengembangan Peternakan Tropis. Special Edition Bulan Oktober Buku I: $35-39$.

Tanari, M. 2001. Usaha Pengembangan Sapi Bali Sebagai Ternak Lokal Dalam Menunjang Pemenuhan Kebutuhan Protein Asal Hewani Di Indonesia.

http://rudyct.250x.com/sem1_012/m_t anari.html.

Zaid, M.M. 2009. Penampilan sapi bali jantan muda yang diberikan ransum komplit. Universitas Hasanuddin. Makassar. 